\title{
Physical Environment Factors With Events Of Home Lung Tuberculosis In Public Health Bonto Bahari
}

\author{
Arum Dani ${ }^{1}$, Andi Suswani ${ }^{2}$, Asri ${ }^{3 *}$ \\ Nursing Study Program, Stikes Panrita Husada Bulukumba, Indonesia ${ }^{1}$ \\ Family And Community Nursing Department, Stikes Panrita Husada Bulukumba, Indonesia 2,3
}

*Corresponding Autor : asriiffat@gmail.com

\begin{abstract}
Tuberculosis is a contagious disease caused by the bacteria Mycobacterium Tuberculosis which is spread through droplets of people who have been infected with tuberculosis bacilli. Pulmonary tuberculosis is still a challenge in public health problems both regionally, nationally, and globally. According to the World Health Organization (WHO) in 2015, there were 10.4 million new TB cases and nearly $75 \%$ of pulmonary tuberculosis patients were economically productive age groups. . The purpose of this study was to determine the physical environmental factors of the house with the incidence of pulmonary tuberculosis at the Bonto Bahari Health Center in 2020. The research method used was using analytical research methods with a case-control approach (case-control) where subjects, namely cases and controls were known and selected based on the output ( out came), then looked back (back ward) about the history of the research exposure status experienced by the subject. The population in this study was about 40 people and the sample in this study amounted to 80 because the researcher took 40 controls. The results of the analysis using the Wilcoxon and Mc Nemar tests, with the results obtained by the value of ventilation ( $p$-value $=0.001$ ) then Ho is rejected and Ha is accepted. The type of floor obtained value ( $p$-value $=1,000$ ) then Ho is accepted and Ha is rejected. The type of wall obtained value ( $\mathrm{p}$-value $=0.002$ ) then Ho is rejected and Ha is accepted. Occupancy density obtained value ( $\mathrm{p}$ value $=0.582$ ) then Ho is accepted and $\mathrm{Ha}$ is rejected. The conclusion of this study There is a relationship between ventilation and the incidence of pulmonary tuberculosis, there is a relationship between the type of wall and the incidence of pulmonary tuberculosis and there is no relationship between floor type and occupancy density with the incidence of pulmonary tuberculosis.
\end{abstract}

Key words: Home, Physical Environment, Tuberculosis

\section{INTRODUCTION}

Health development as part of the national building is carried out gradually and continuously and to improve the overall welfare of the people (Mawardi et al., 2019). According to the World Health Organization (WHO) in 2015, Tuberculosis is estimated to still affect 9.6 million people and cause 1.2 million deaths. In 2014 and 2015 there were 10.4 million new tuberculosis cases and nearly $75 \%$ of pulmonary tuberculosis patients were economically productive age groups (15-50 years). India, Indonesia and China are countries with pulmonary tuberculosis (Yigibalom et al., 2019). Data from Riskesdas 
(2018) states that patients with pulmonary tuberculosis in 2013 amounted to $0.4 \%$, and did not experience an increase in 2018. In Indonesia the incidence of tuberculosis is in the second place with the number of new cases after India in 2016 of 893 cases and increases if compared to 2015, only around 729 cases, while in Central Java in 2016, there were 115.36 cases per 100,000 population, more than in 2015, namely 115.17 per 100,000 population (Pradita et al., 2018).

According to data from the Disease Control and Environmental Management (P2PL) at the Health Office of the province of South Sulawesi, there were 8,939 patients with pulmonary tuberculosis. This figure is increasing compared to the previous year which was only 7,783 patients with pulmonary tuberculosis. South Sulawesi, the highest number of pulmonary tuberculosis patients was in Makassar, amounting to 1,737 patients, compared to Bulukumba district who suffered from Tuberculosis in the 9th number of 435 patients (Angraini Hasri, 2013).

Based on data from the Bulukumba District Health Office, in the last 3 years, there was an increase in 2017 as much as $3.24 \%$ of 324 patients with Acid Resistant Basil (+), while in 2018 patients with pulmonary tuberculosis experienced an increase of 3.38\% from 338 patients with Acid Resistant Basil (+) and in 2019 pulmonary tuberculosis patients experienced a very high increase of $6.51 \%$ from 651 acid-resistant bacilli patients $(+)$. Based on the results of data obtained in the work area of the Bonto Bahari Health Center in the last 3 years from 2017, there were 39 patients with pulmonary tuberculosis, in 2018 there were a decrease of 25 patients with pulmonary tuberculosis and again in 2019 there were 40 tuberculosis patients.

Pulmonary tuberculosis is an infectious disease caused by mycobacterium tuberculosis, which is spread through droplets of people infected with Bacillus tuberculosis who are inhaled and enter the respiratory tract. Droplets contain bacteria that remain in the air for several hours. Patients with pulmonary tuberculosis in adults are estimated to lose 3 to 4 months of working time, resulting in an annual loss of household income of around 20-30\% with the physical environment of the house and other environments. (Anggraeni et al., 2015). According to a survey I conducted from several houses, I found houses that did not meet the requirements such as the type of floor that used the ground, the type of wall that used unplastered masonry, the density of occupancy and ventilation. The physical environment of the house that does not meet the requirements will be a high risk factor for the transmission and incidence of pulmonary 
tuberculosis in Indonesia. The source of transmission of this disease is closely related to housing sanitation conditions which affect the number or density of germs in the house, including Mycobacterium Tuberculosis. The relationship is influenced by the cleanliness of the air because the house is too narrow or too many residents, the room will lack oxygen so that it will cause a decrease in body resistance, making it easier for disease to occur (Amirus and Herleni, 2017). From previous studies, poor housing conditions are a reflection of the low socioeconomic status associated with tuberculosis. People with low education, employment, income and social class tend to have houses with overcrowded conditions, insufficient ventilation and polluted spaces. Factors that increase tuberculosis include: ventilation, type of floor, density of occupancy and type of house walls. (Anwary et al., 2016).

Based on the description above, I am interested in researching "Home Physical Environmental Factors with the Incidence of Pulmonary Tuberculosis at Bonto Bahari Community Health Center in 2020" because I see many houses that do not meet the requirements such as insufficient ventilation, floor types, occupancy density and types of house walls.

\section{MATERIAL AND METHODS}

This study used an analytical research design with a case control approach (case control) in which subjects, namely cases and controls, were known and selected based on certain out came, then looked back (back ward) about the history of the research exposure status experienced by the subject (Nursalam, 2016). In this study, the researcher wanted to find out whether there were physical environmental factors in the house with the incidence of pulmonary tuberculosis at the Bonto Bahari health center in 2020.

Population is a generalization area consisting of objects or subjects that have certain quantities and characteristics set by researchers to study and then draw conclusions (Sugiyono, 2017). The population in this study were all patients with pulmonary tuberculosis at Bonto Bahari health center totaling 40 people. The sample is part of the total characteristics of the population (Sugiyono, 2017). The sample is 80 people.

The research instrument is a tool used to measure natural and social phenomena observed by researchers to observe, measure or assess a phenomenon (Sugiyono, 2017). The instrument in this study was an observation sheet that used an ordinal scale with 2 assessment criteria, namely risk or no risk. Data analysis was carried out to answer the 
hypothesis in the study. For this reason, a suitable statistical test or in accordance with the research variables was used. Data analysis in this study was carried out through Univariate analysis is used to describe descriptively the frequency distribution and proportion of each accurate variable, both the independent variable and the dependent variable. Univariate analysis aims to explain or describe the characteristics of each research variable (Sujarweni, 2014).

The bivariate analysis was conducted to determine whether there was a relationship between the independent variable and the dependent variable. The statistical test used was the Wilcoxon test and the NcNemar test. This test aims to see whether or not there is a significant difference in the proportion between the observed frequency distribution and the expected significant degree of 0.05 if the value $<0.05$ means that there is a significant difference (Ho is rejected) while the P-value $>0.05$ means there is no significant difference ( Ho is accepted), estimating the amount of risk of the independent variable on the dependent variable is carried out by calculating the Odd Ratio (OR).

\section{RESULTS}

Table 1. Characteristics of Respondents Based on age, gender, occupation, education and income

\begin{tabular}{ccc}
\hline Respondent Characteristics & Case & Control \\
\hline Age & $33(82.5 \%)$ & \\
Adult & $7(17.5 \%)$ & $34(85.0 \%)$ \\
Seniors & & $6(15.0 \%)$ \\
\hline Gender & $24(60.0 \%)$ & \\
Male & $16(40.0 \%)$ & $13(32.5 \%)$ \\
Female & & $27(67.5 \%)$ \\
\hline Profession & $22(55.0 \%)$ & \\
Work & $18(45.0 \%)$ & $20(50.0 \%)$ \\
Does not work & & $20(50.0 \%)$ \\
\hline Education & $15(37.5 \%)$ & \\
SD & $7(17.5 \%)$ & $20(50.0 \%)$ \\
Junior High & $18(45.0 \%)$ & $13(32.5 \%)$ \\
High school & & $7(17.5 \%)$ \\
\hline Income & $5(12.5 \%)$ & - \\
No income & $21(52.5 \%)$ & $21(52.5 \%)$ \\
$100-1,000,000$ & $13(32.5 \%)$ & $17(42.5 \%)$ \\
$1,100,000-2,000,000$ & $1(2.5 \%)$ & $2(5.0 \%)$ \\
\hline 2,100,000-3,000,000 & $\mathbf{8 0}$ & $\mathbf{1 0 0 , 0} \%$ \\
\hline Amount & & \\
\hline
\end{tabular}

Based on Table 1, it can be seen that the characteristics of the age respondents in the case group were more than 33 respondents (82.5\%) as well as the control group which was more in adults as many as 34 respondents (85.0\%). Characteristics of respondents 
based on gender in the case group were 24 respondents $(60.0 \%)$ more male than in the control group with 27 female respondents (67.5\%).

Characteristics of respondents based on occupation in the case group were more than 22 respondents (55.0\%) and in the control group who worked 20 respondents $(50.0 \%)$. Characteristics of respondents based on education in the case group with a higher SMA 18 respondents (45.0\%) while in the control group higher SD 20 respondents $(50.0 \%)$. Characteristics of respondents based on income in the case group are more numerous, namely those who have an income of 100-1,000,000 21 respondents (52.5\%) as well as in the control group who have an income of 100-1,000,000 21 respondents (52.5\%).

Table 2. Distribution based on the number of pulmonary tuberculosis, ventilation, floor type, wall type, occupancy density

\begin{tabular}{lccc}
\hline variable & Frequency & \multicolumn{2}{c}{ Percentage (\%) } \\
\hline TB sufferers & 40 & \multicolumn{2}{c}{$100.0 \%$} \\
Not a TB patient & 40 & \multicolumn{2}{c}{$100.0 \%$} \\
\hline Amount & $\mathbf{8 0}$ & $\mathbf{1 0 0 . 0 \%}$ \\
\hline Ventilation area & Mean & Minimum & Maximum \\
\hline Case group & 29.3075 & 1.20 & 74.10 \\
\hline Control group & 22.1350 & 1.20 & 74.10
\end{tabular}

Based on table 2, it shows that the average (mean) ventilation was more in the case group of 29.3075 compared to the control group of 22.1350. Respondents frequency based on the type of floor in the case and control group is the same, namely the more who are not at risk 31 respondents (77.5\%) as well as more control groups who are not at risk 31 respondents $(77.7 \%)$.

Table 3. Respondents Frequency Distribution by Floor Type

\begin{tabular}{ccc}
\hline Floor Type & Case & Control \\
\hline It's risky & $9(22.5 \%)$ & $9(22.5 \%)$ \\
Not risky & $31(77.5 \%)$ & $31(77.5 \%)$ \\
\hline Amount & $\mathbf{4 0 ( 1 0 0 . 0 \% )}$ & $\mathbf{4 0}(\mathbf{1 0 0 . 0 \% )}$
\end{tabular}

Respondents frequency based on the type of floor in the case and control group is the same, namely the more who are not at risk 31 respondents (77.5\%) as well as more control groups who are not at risk 31 respondents (77.7\%). 
Table 4. Frequency Distribution of Respondents by Floor and Wall Type

\begin{tabular}{lcc}
\hline Wall type & Case & Control \\
\hline It's risky & $23(57.5 \%)$ & $9(22.5 \%$ \\
Not risky & $17(42.5 \%)$ & $31(77.5 \%)$ \\
\hline Amount & $\mathbf{4 0 ( 1 0 0 . 0 \% )}$ & $\mathbf{4 0 ( 1 0 0 . 0 \% )}$ \\
\hline
\end{tabular}

Based on table 4, the frequency of respondents based on the type of wall in the case group with more risk was 23 respondents (57.5\%) while in the control group more who were not at risk were 31 respondents (77.5\%).

Table 5. Respondent Frequency Distribution Based on Occupancy Density

\begin{tabular}{lccc}
\hline Occupancy Density & Mean & Minimum & Maximum \\
\hline Case & 13.4312 & 5.30 & 74.10 \\
\hline Control & 14.2913 & 5.50 & 27.00 \\
\hline
\end{tabular}

Based on table 5. it shows the average value (Mean) of occupancy density in the case group as much as 13.4312 while in the control group it is 14.2913.

Table 6. Analysis of the relationship between ventilation and pulmonary tuberculosis

\begin{tabular}{llrc}
\hline \multicolumn{1}{c}{ Tuberculosis } & & \\
\hline Ventilation Area & Mean & Std.Deviation & P Value \\
\hline Case group & 29.3075 & 27.08431 & 0.001 \\
\hline Control Group & 22.1350 & 23.85466 & \\
\hline
\end{tabular}

Based on Table 6, it is known that the average (mean) value is more, namely in the case group as much as 29.3075 compared to the control group as much as 22.1350 . Based on the results of statistical analysis using the Wilcoxon test, the significant value was 0.001 ( $\mathrm{p}<0.05$ ), so Ho was rejected and Ha was accepted. From these results it can be concluded that there is a relationship between ventilation and the incidence of pulmonary tuberculosis at the Bonto Bahari Center.

Table 7. Analysis of the Relationship Between Floor Types and the Incidence of Pulmonary Tuberculosis

Tuberculosis

\begin{tabular}{lccccccc}
\hline Floor type & \multicolumn{2}{c}{ Case } & \multicolumn{2}{c}{ Control } & \multicolumn{2}{c}{ Amount } & P Value \\
\hline & $\mathrm{F}$ & $\%$ & $\mathrm{~F}$ & $\%$ & $\mathrm{~F}$ & $\%$ & \\
\hline It's risky & 9 & $22.5 \%$ & 9 & $22.5 \%$ & 18 & $22.5 \%$ & 1.000 \\
\hline Not risky & 31 & $77.5 \%$ & 31 & $77.5 \%$ & 62 & $77.5 \%$ & \\
\hline Amount & $\mathbf{4 0}$ & $\mathbf{1 0 0 . 0 \%}$ & $\mathbf{4 0}$ & $\mathbf{1 0 0 . 0 \%}$ & $\mathbf{8 0}$ & $\mathbf{1 0 0 . 0 \%}$ & \\
\hline
\end{tabular}




\section{COMPRAHANSWE HiBAW CARE}

Based on Table 5.8, it is known that the case and control groups are the same, namely the more case group who are not at risk as many as 31 respondents (77.5\%) as well as the more control group who are not at risk as many as 31 respondents (77.5\%). Based on the results of statistical analysis using the McNemar test, the significant value was 1,000 ( $p>0.05$ ), so Ho was accepted and Ha was rejected. From these results it can be concluded that there is no relationship between the type of floor with the incidence of pulmonary tuberculosis at Bonto Bahari Center.

Table 8. Analysis of the relationship between wall types and the incidence of pulmonary tuberculosis

\begin{tabular}{|c|c|c|c|c|c|c|c|}
\hline \multicolumn{8}{|c|}{ Tuberculois } \\
\hline \multirow[t]{2}{*}{ Wall type } & \multicolumn{2}{|c|}{ Case } & \multicolumn{2}{|c|}{ Control } & \multicolumn{2}{|c|}{ Amount } & \multirow[t]{2}{*}{ P Value } \\
\hline & $\mathrm{F}$ & $\%$ & $\mathrm{~F}$ & $\%$ & $\mathrm{~F}$ & $\%$ & \\
\hline It's risky & 23 & $57.5 \%$ & 9 & $22.5 \%$ & 32 & $40.0 \%$ & 0.002 \\
\hline Not risky & 17 & $42.5 \%$ & 31 & $77.5 \%$ & 48 & $60.0 \%$ & \\
\hline Amount & 40 & $100.0 \%$ & 40 & $100.0 \%$ & 80 & $100.0 \%$ & \\
\hline
\end{tabular}

Based on Table 8, it is known that the more respondents in the case group, namely those at risk, were 23 respondents (57.5\%), while the more respondents in the control group who were not at risk were 31 respondents (77.5\%). Based on the results of statistical analysis using the McNemar test, the significant value was $0.002(\mathrm{p}<0.05)$, so Ho was rejected and Ha was accepted. From these results it can be concluded that there is a relationship between the type of wall and the incidence of pulmonary tuberculosis at Bonto Bahari Center.

Table 9. Analysis Of The Relationship Between Occupancy Density And Incidence Of Pulmonary Tuberculosis

\begin{tabular}{lccc}
\hline Tuberculosis & & & \\
\hline Occupancy Density & Mean & Std. Deviation & P Value \\
\hline Case Group & 13.4312 & 5.29410 & 0.582 \\
\hline Control Group & 14.2913 & 7.53334 & \\
\hline
\end{tabular}

Based on Table 9 it is known that the average (Mean) occupancy density in the control group was 14.2913 mean (5.53334) compared to the case group as much as 13.4312 mean (7.29410). Based on the results of statistical analysis using the Wilcoxon test, the significant value was 0.582 ( $\mathrm{p}>0.05$ ), so Ho was accepted and Ha was rejected. From these results it can be concluded that there is no relationship between occupancy density with the incidence of pulmonary tuberculosis at Bonto Bahari Center. 


\section{DISCUSSION}

Based on the results of research conducted in the working area of the Bontobahari Community Health Center, it was found that there was a relationship between ventilation and the incidence of pulmonary tuberculosis in the working area of the Bonto Bahari Puskesmas. This is because inadequate ventilation causes light not to enter the house which results in increased humidity in the house. Thus the pulmonary tuberculosis germ will grow well and can infect residents of the house.

From the table above shows that in the case group more at risk than ventilation that is not at risk. In the control group where the number at risk is the same as those who are not at risk, namely those who are at risk and those who are not at risk.

Similar to research conducted by (Anggraeni et al., 2015) in Malang Regency, which found that there was a significant relationship between ventilation and the incidence of pulmonary tuberculosis, which showed that people who lived in a house with an area of ventilation who did not meet health requirements had 15 times the risk. for pulmonary tuberculosis compared to people living in a well-ventilated household that meets health requirements. This is the same as research conducted by (Mawardi et al., 2019) which states that there is a relationship between ventilation and the incidence of pulmonary tuberculosis, meaning that respondents with home ventilation do not meet the risk of experiencing pulmonary TB (+) 2 times compared to home ventilation that meets terms.

In contrast to research conducted by (Imaduddin \& Setiani, 2019) in the city of Tanjungpinang, there is no significant relationship between ventilation and the incidence of pulmonary tuberculosis, which indicates that the proportion of houses that have an area of ventilation is more in the case group compared to the control group.

Ventilation is a hole or air that must be present in the house. This vent functions as an exchange in and out of air. According to Permenkes RI No. 1077 / Menkes / Per / V / 2011 regarding the guidelines for air sanitation 2011 the requirement for sufficient ventilation area is at least $10 \%$ that poor or inadequate air exchange can lead to the proliferation of microorganisms that can cause human health problems. Bacteria will last a long time in the house if there is minimal ventilation at home (Mawardi et al., 2019).

According to the investigators' assumptions, ventilation has a role in pulmonary TB transmission. Based on the research, one of the factors that influenced the lack of ventilation holes in the respondent's house was that the average respondent said and they reasoned that too much ventilation or too large ventilation holes resulted in dust 
entering the house when a lot of wind entered. Ventilation conditions that do not meet health requirements cause reduced indoor air exchange which will result in diseasecausing bacteria, especially tuberculosis bacteria that can reproduce. In this condition, there is no good air exchange, there will be an increase in the number and concentration of bacteria, so the risk of disease transmission will be even higher. It is recommended that the health center provide counseling on the requirements for a healthy house and meet the requirements so that the need for sufficient ventilation for air circulation. Therefore, home ventilation is necessary to increase the area.

Based on the results of research conducted in the working area of the Bontobahari puskesmas, it was found that there was no relationship between the type of floor and pulmonary tuberculosis in the working area of the Bonto Bahari puskesmas. This is because the researcher observed the respondent's house regarding the type of floor in the respondent's house and almost half of the respondents have a permanent type of house, on average it meets the requirements such as having been tiled.

This study is the same as research conducted by (Hamidah et al., 2015) which shows that there is no significant relationship or that there is no relationship between floor type and the incidence of pulmonary tuberculosis and is also the same as research conducted by (Anwary, 2015). ) by showing that there is no relationship between floor types and the incidence of pulmonary tuberculosis in West Java with the soil category having a 1.264 times greater probability of increasing the risk factors for pulmonary TB incidence compared to non-ground floor types.

This research is different from the research conducted by (Mawardi et al., 2019) which shows there is a relationship between the type of floor and patients with pulmonary TB AFB (+) in the work area of the Lhok Bengkuang Puskesmas, Tapaktuan District, Selatah Aceh Regency in 2018, which means the respondent with the floor houses that do not meet the requirements have the risk of experiencing pulmonary tuberculosis $(+) 1$ fold compared to the floors of houses that meet the requirements.

A good floor is made of waterproof material. If the floor is damp, it will be a good development tool for TB bacteria (Mawardi et al., 2019).

According to the researchers' assumptions, the type of floor plays an important role in pulmonary tuberculosis. Some of the respondents' houses have met the requirements, some respondents have realized that it is important to install ceramics so that there is not a lot of dust in the house and it is easy to clean compared to dirt floors or have not 
installed ceramics only a few respondents have such floors. So that the type of floor has nothing to do with the incidence of pulmonary tuberculosis at the Bonti Bahari health center.

Based on the results of research conducted in the working area of the Bontobahari puskesmas, it was found that there was a relationship between the type of wall and the incidence of pulmonary tuberculosis at the Bonto Bahari puskesmas. The type of wall in the house will affect humidity and the chain of transmission of pulmonary tuberculosis. A person who lives with a non-permanent / semi-permanent type of wall compared to a person who lives with a permanent or qualifying wall type. This study shows that in the case group more at risk than in the control group more who are not at risk. This research is the same as research conducted by (Wulandari, 2012) which shows there is a relationship between the type of wall and the incidence of pulmonary tuberculosis in the working area of the Bandarharjo Public Health Center, Semarang City in 2011.

Walls are a room divider, apart from being a room divider, they also function to withstand wind and dust, walls are equipped with ventilation facilities for regulating air circulation. Walls that meet the requirements are watertight walls. The type of wall also has a role in the process of bacteria reproduction, through wall moisture. However, not everyone is able to repair or install waterproof walls, this is influenced by economic factors. This is supported by researchers conducted by (Anggraeni et al., 2015) who show that there is no relationship between wall types and the incidence of pulmonary TB in the working area of the Gondang-legi Community Health Center.

The type of wall in the house will affect humidity and transmission of tuberculosis. If there are residents who suffer from Tuberculosis, pathogenic bacteria may also be present in the dust that sticks to the walls. Therefore, the type of wall that should be used for a house is permanent and impermeable to water, which is made of plastered wall or coal. The watertight walls of the house serve to support the roof, hold the house from wind or rain and protect heat or dust (Mawardi et al., 2019). According to the assumptions of researchers, most of the respondents' houses do not meet the requirements, such as the walls that are not plastered compared to those that meet the requirements such as walls or plastered. at the Bonto Bahari clinic there is a relationship between the type of wall and the incidence of pulmonary tuberculosis.

Based on the results of research conducted in the work area of the Bontobahari puskesmas, it was found that there was no relationship between occupancy density and 
the incidence of pulmonary tuberculosis at the Bonto Bahari puskesmas. This is because when the researcher observed the respondent's house was relatively large and the number of residents in the house was a little on average. This can also be seen from the frequency distribution of respondents who are not at risk.

This study shows that more cases in the group are not at risk, while in the control group more who are not at risk.

This research is the same as research conducted by (Anwary, 2015) which means that there is no relationship between occupancy density and the incidence of pulmonary tuberculosis in West Java because the denser the occupancy, the probability is 1.047 times compared to houses that are not densely populated in increasing the risk of TB incidence. lungs in West Java.

This research is different from the research conducted by (Mawardi et al., 2019), it shows that there is a relationship between occupancy density with pulmonary TB patients in the work area of the Lhok Bengkuang Puskesmas, Tapaktuan District, South Aceh Regency in 2018, which means that respondents with occupancy density do not meet the requirements the risk of experiencing pulmonary TB is 5 times higher than the density of residents who meet the requirements and also different from the research conducted by (Anggraeni et al., 2015) which means there is no relationship between occupancy density and the incidence of pulmonary TB because most of the respondents' houses are quite large and only occupied by 3-4 people which means there is no density of occupancy in one house.

The occupancy density is the ratio between the floor area of the house and the number of family members in one house. The area of the house that is not proportional to the number of residents will cause congestion. This is unhealthy because in addition to causing a lack of oxygen, if one of the family members is infected with an infectious disease, especially tuberculosis, it will easily spread to other family members.

According to the researchers' assumptions, occupancy density has a role in the transmission of pulmonary TB. Nearly half of the occupancy density has met the requirements because the house in the working area of the puskesmas is a relatively large house, so there is no relationship between occupancy density and the incidence of pulmonary tuberculosis at the Bonto Bahari puskesmas. Several respondents said that a large house with relatively few occupants did not cause difficulties when carrying out activities at home. Therefore, patients with pulmonary tuberculosis, especially those with 
densely populated homes, must make good use of air ventilation by getting used to opening windows every day, especially in the morning, separate eating and drinking utensils from sufferers and not throwing phlegm in random places to prevent transmission to other family members. .

\section{CONCLUSION}

The conclusion of this study is that there is a relationship between ventilation and the incidence of pulmonary tuberculosis, there is no relationship between the type of floor and the incidence of pulmonary tuberculosis, there is a relationship between the type of wall and the incidence of pulmonary tuberculosis, there is no relationship between occupancy density and the incidence of pulmonary tuberculosis at Bonto Bahari Public Health Center. . The suggestion of this research is the importance of counseling about a healthy home, especially the condition of adequate ventilation for pulmonary TB patients who live in densely populated homes. The ventilation or windows must always be open every day, especially in the morning so that sunlight can enter the house to kill TB germs.

\section{REFERENCES}

AMIRUS, K. \& HERLENI, E. 2017. PENGARUH KUALITAS FISIK RUMAH DAN KEPADATAN PENGHUNI RUMAH TERHADAP PENYAKIT TUBERKULOSIS PARU DI WILAYAH KERJA PUSKESMAS KALIBALANGAN KABUPATEN LAMPUNG UTARA. JURNAL DUNIA KESMAS, 6.

ANGGRAENI, S. K., RAHARJO, M. \& NURJAZULI, N. 2015. Hubungan Kualitas Lingkungan Fisik Rumah dan Perilaku Kesehatan dengan Kejadian Tb Paru di Wilayah Kerja Puskesmas Gondanglegi Kecamatan Gondanglegi Kabupaten Malang. Jurnal Kesehatan Masyarakat (e-Journal), 3, 559-568.

ANGRAINI HASRI, F. 2013. STUDI MUTU PELAYANAN SENTRA DIRECTLY OBSERVED TREATMENT SHORT-COURSE (DOTS) DI BALAI BESAR KESEHATAN PARU MASYARAKAT SULAWESI SELATAN TAHUN 2013.

ANWARY, A. Z., LAZUARDI, L., HASANBASRI, M., MANSUR, F. \& BAGIAN, P. 2016. Hubungan Kondisi Lingkungan Fisik Rumah Dengan Kejadian Tuberkulosis Paru Di Jawa Barat (Analisis Data Riskesdas 2013). Jurnal Kesehatan Indonesia, 6.

BLACK, J. M. \& HAWKS, J. H. 2014. Keperawatan Medikal Bedah. Edisi 8, Jilid 3. Elsevier. Singapura: PT Salemba Medika.

DEWI, S. M. \& KOMANG, N. 2018. Hubungan Kualitas Fisik Rumah Dengan Kejadian TBC Paru Di Wilayah Kerja Puskesmas I Denpasar Selatan Tahun 2018. Jurusan Kesehatan Lingkungan.

EUFEMIA, E., EDWIN, E., NILUH, N. \& SHITA, S. 2019. Hubungan Tingkat Pencahayaan, Kelembaban Udara, dan Ventilasi Udara dengan Faktor Risiko Kejadian TB Paru BTA Positif di Desa Jatikalang Kecamatan Krian Kabupaten Sidoarjo. Jurnal Ilmiah Kedokteran Wijaya Kusuma, 8, 118-130.

HIDAYAT, A. A. 2014. Metode Penelitian Keperawatan Dan Teknik Analisa Data,. In: MEDIKA., S. (ed.). Jakarta Selatan, . 
IHSAN, H. 2015. VALIDITAS ISI ALAT UUKUR PENELITIAN: KONSEP DAN PANDUAN PENILAIANNYA. PEDAGOGIA, 13, 173-179.

KALIGIS, G. I., PINONTOAN, O. R. \& JOSEPH, W. B. 2019. FAKTOR KONDISI LINGKUNGAN FISIK RUMAH YANG BERHUBUNGAN DENGAN KEJADIAN TUBERKULOSIS PARU DI KELURAHAN PAKOWA KECAMATAN WANEA KOTA MANADO. KESMAS, 8.

KANDAU, G. D. \& POSANGI, J. 2015. Hubungan kualitas lingkungan fisik rumah dengan kejadian tuberkulosis paru di wilayah kerja puskesmas perawatan Siko Kecamatan Ternate Utara Kota Ternate Provinsi Maluku Utara. eBiomedik, 3.

LUBIS, F. H. \& SIMAMORASYSKA, S. 2019. HUBUNGAN KONDISI FISIK RUMAH DENGAN KEJADIAN PENYAKIT TUBERKULOSIS PARU DI WILAYAH KERJA PUSKESMAS SIGOMPUL KEC. LINTONGNIHUTA KAB. HUMBANG HASUNDUTAN TAHUN 2018. JURNAL KESMAS DAN GIZI (JKG), 1, 38-44.

MAWARDI, M., SAMBERA, R. \& HAMISAH, I. 2019. Studi Hubungan Antara Faktor Lingkungan Fisik Rumah Dengan Penderita TB Paru BTA di Aceh Selatan. Jurnal Serambi Engineering, 4, 406-415.

NAGA, S. S. 2013. Buku Panduan Lengkap Ilmu Penyakit Dalam. Jogjakarta: Diva Press

NIZAR, M. 2017. Pemberantasan dan Penanggulangan Tuberkulosis. Yogyakarta: Gosyen Publishing.

NURSALAM, N. 2016. Metodologi Penelitian Ilmu Keperawatan. Salimba Medika.

PADILAH 2013. Asuhan keperawatan penyakit dalam. Yogyakarta: Nuha Medika.

PRADITA, E. R., SUHARTONO, S. \& DEWANTI, N. A. Y. 2018. KONDISI FAKTOR FISIK RUMAH YANG TERKAIT DENGAN TUBERKULOSIS PARU DI PUSKESMAS BANDARHARJO KOTA SEMARANG. Jurnal Kesehatan Masyarakat (e-Journal), 6, 94-102.

RETNO WULAN ARUM SARI, A. K. 2014. Keperawatan Medikal Bedah Manajemen Klinis Untuk Hasil Yang Diharapkan Edisi 8. Singapore: Cv Pentasada Media Edukasi

SARTONO 2011. Aplikasi Florance Nightingale dalam pelayanan keperawatan dan Aplikasi Kasus yang Relevan.

SMELTZER, S. C. 2014. Keperawatan Medikal Bedah Brunner\&Suddarth 12 ed. jakarta: Egc.

SUGIYONO, P. 2017. Metode Penelitian Bisnis: Pendekatan Kuantitatif, Kualitatif, Kombinasi, dan R\&D. Penerbit CV. Alfabeta: Bandung.

SUJARWENI, W. 2014. Metodologi Penelitian Keperawatan. Yogyakarta: Gava Media. SURYO 2010. Gangguan Sistem Pernapasan. yogyakarta: Ariesta.

SYAMSUDDIN ET.AL. 2016. Pedoman Praktis Metode Penelitian Internal. Ponorogo: CV. Wade Group.

TANTO, C. 2014. Kapita Selekta Kedokteran Edisi 4.Jakarta: Media Aesculapius.

TUNRU, I. A. 2016. Mycobacterium Tuberkulosis 0-8.

YIGIBALOM, N., SULISTIYANI, S. \& NURJAZULI, N. 2019. Faktor Risiko Kebiasaan Tinggal di Rumah Etnis dan Membuang Dahak Sembarang pada Kejadian TB Paru Di Kabupaten Jayawijaya, Papua. Jurnal Kesehatan Lingkungan Indonesia, 18, 1-7.

ZULKAHFI 2015. Asuhan Keperawatan Komunitas. tangerang selatan BINARUPA AKSARA Publisher.

Anwary, A. Z. (2015). Hubungan Kondisi Lingkungan Fisik Rumah Dengan Kejadian Tuberkulosis Paru Di Jawa Barat (Analisis Data Riskesdas 2013). 6.

Imaduddin, D., \& Setiani, O. (2019). Hubungan Kondisi Fisik Rumah Dan Perilaku 
Dengan Kejadian Tb Paru Di Wilayah Kerja Puskesmas Batu 10 Kota Tanjungpinang. Jurnal Kesehatan Masyarakat (e-Journal), 7(3), 8-14.

Sambera, R., \& Hamisah, I. (2019). 851-1595-1-Sm. IV(1), 406-415.

Wulandari, S. (2012). Hubungan Lingkungan Fisik Rumah Dengan Kejadian Tuberkulosis Paru. Unnes Journal of Public Health., 1(1), 3-6.

https://doi.org/10.15294/ujph.v1i1.180 